\title{
获苓飲合半夏厚朴湯治験
}

\author{
関矢 信康 ${ }^{\mathrm{a}}$ 並木 隆雄 $\mathrm{a}$ 笠原 裕司 $\mathrm{a}$ \\ 地野 充時 $\mathrm{a}$ 平崎 能郎 $\mathrm{b}$ 小川 恵子c \\ 来村 昌紀 $\mathrm{c}$ 橋本すみれc 大野 賢二 $\mathrm{a}$ \\ 寺澤 捷年b \\ a 千葉大学大学院医学研究院先端和漢診療学講座，千葉， $=260-8670$ 千葉市中央区亥鼻1-8-1

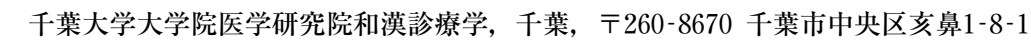

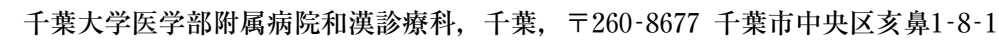

\section{Cases Report of Bukuryoingohangekobokuto}

\author{
Nobuyasu SEKIYA $^{\mathrm{a}}$ Takao NAMIKI $^{\mathrm{a}}$ Yuji KASAHARA ${ }^{\mathrm{a}}$ \\ Atsushi CHINO $^{\mathrm{a}}$ Yoshiro HIRASAKI ${ }^{\mathrm{b}} \quad$ Keiko OGAWA $^{\mathrm{c}}$ \\ Masaki RAIMURA $^{\mathrm{c}} \quad$ Sumire HASHIMOTO $^{\mathrm{c}}$ Kenji OHNO $^{\mathrm{a}}$ \\ Katsutoshi TERASAWA ${ }^{b}$
}
a Department of Frontier Japanese Oriental (Kampo) Medicine, Graduate School of Medicine, Chiba University, 1-8-1 Inohana, Chuo-ku, Chiba 260-8670, Japan
b Department of Japanese Oriental (Kampo) Medicine, Graduate School of Medicine, Chiba University, 1-8-1 Inohana, Chuo- ku, Chiba 260-8670, Japan
c Department of Japanese Oriental (Kampo) Medicine, Chiba University Hospital, 1-8-1 Inohana, Chuo-ku, Chiba 260-8677, Japan

\begin{abstract}
We report on 3 patients who presented with symptoms of $K i$ obstruction, $K i$ deficiency, and disorder of the body's fluid metabolism, successfully treated with bukuryoingohangekobokuto. In our experience, bukuryoingohangekobokuto has been effective in 25 of the 30 patients ( 6 men and 24 women) to whom is has been administered, who also presented with $K i$ obstructions, $K i$ deficiencies and disorders of the body's fluid metabolism as mentioned above. The most common subjective symptom in all these effectively-treated patients was hot flashes. Other signs were epigastric pain or discomfort accompanied by chest signs and symptoms, such as palpitations, heartburn, chest oppression or dyspnea. The most common objective findings in these effectivelytreated patients were pulsation at the pit of the stomach and navel, and a fluid sound in the stomach upon palpation. Based on our experiences, we believe that prescription of bukuryoingohangekobokuto is best indicated when the presence of the above-mentioned symptoms and findings has been confirmed.

Key words : bukuryoingohangekobokuto, hot flash, chest symptoms, pulsation at pit of stomach and navel, fluid sound in the stomach upon palpation

\section{要旨}

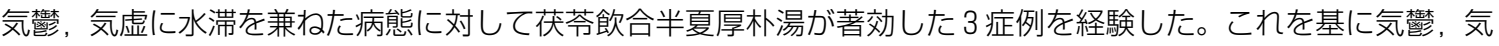
虚に水滞を兼ねた30症例（男性 6 例, 女性24例）に茯苓飲合半夏厚朴湯を投与したところ25症例で有効であった。 有効例ではのぼせを自覚する者が比較的多くみられた。有効例で心窝部痛あるいは心窩部不快感を訴える場合には 必す動悸, 胸焼け, 胸部圧迫感, 呼吸困難などの胸部症状を伴った。他覚所見では腹部動悸, 胃部振水音が有効例 に高率に認められた。获苓飲合半夏厚朴湯を投与する場合に上記の自他覚所見の有無を確かめることでより高い精 度で処方決定しうる可能性が示唆された。
\end{abstract}

キーワード：获苓飲合半夏厚朴湯, のぼせ, 胸部症状, 腹部動悸, 胃部振水音

\author{
緒言 \\ 获苓飲合半夏厚朴湯の出典は不詳であるが，近年 \\ のわが国において工夫された処方と考えられてい
}

る ${ }^{1)}$ 。大塚敬節は「半夏厚朴湯證の如くにして，食 欲不振, 胃内停水著明の者には, 予は習慣上, 获苓

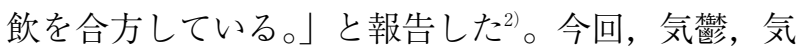


表 1 症例の背景および自覚症状

\begin{tabular}{|c|c|c|c|}
\hline 症例 & 年齢・性 & 臨床診断 & 自覚症状 \\
\hline 1 & $36 \mathrm{~F}$ & 不妊症 & 腹満、全身倦怠感、のぼせ \\
\hline 2 & $49 \mathrm{~F}$ & 乳癌術後、更年期症候群、慢性胃炎 & のぼせ、心窩部不快感、胸焼け \\
\hline 3 & $44 \mathrm{~F}$ & 過敏性腸症候群 & 腹満、下痢、頭重、のぼせ \\
\hline 4 & $47 \mathrm{~F}$ & 更年期症候群、緊張型頭痛 & 腹満、のぼせ、頭痛 \\
\hline 5 & $64 \mathrm{~F}$ & 不安障害、不眠症 & のぼせ、動悸、胸焼け \\
\hline 6 & $57 \mathrm{~F}$ & 更年期症候群、不眠症、不安障害 & 腹満、のぼせ、動悸 \\
\hline 7 & $55 \mathrm{~F}$ & 卵巣癌術後、不安障害 & 動悸、不安、肩甲間部痛 \\
\hline 8 & $58 \mathrm{~F}$ & 慢性胃炎、逆流性食道炎、緊張型頭痛 & のぼせ、頭痛、心窩部不快感、胸焼け \\
\hline 9 & $34 \mathrm{~F}$ & 胃食道逆流（食道噴門形成術後） & 腹満、胸焼け、胸瘏 \\
\hline 10 & $18 \mathrm{~F}$ & リンパ管腫 & のぼせ、全身倦怠感、下肢痛 \\
\hline 11 & $58 \mathrm{~F}$ & 気管支喘息、慢性胃炎 & 全身倦怠感、喘鳴、呼吸困難 \\
\hline 12 & $56 \mathrm{~F}$ & 左腎孟尿管移行部狭窄、左尿管狭窄 & のぼせ、左側腹部痛、陰部痛 \\
\hline 13 & $50 \mathrm{~F}$ & 乳癌術後、慢性鼻炎 & のぼせ、発汗、両肩痛 \\
\hline 14 & $56 \mathrm{~F}$ & 非定型好酸菌症、アレルギー性鼻炎 & のぼせ、肩こり、眼精疲労 \\
\hline 15 & $53 \mathrm{~F}$ & 慢性腎不全、過敏性腸症候群 & 腹満、のぼせ、眩暈、全身倦㤐感 \\
\hline 16 & $52 \mathrm{~F}$ & 膿疮性乾癬、乾癬性関節炎 & のぼせ、両肩痛、背部痛 \\
\hline 17 & $58 \mathrm{~F}$ & 線維笳痛症、逆流性食道炎 & 胸瘏、胸焼け、両肩痛、朝のこわばり \\
\hline 18 & $50 \mathrm{~F}$ & 線維筋痛症、逆流性食道炎、気管支喘息 & 心窩部痛、胸焼け、動悸、呼吸困難 \\
\hline 19 & $30 \mathrm{~F}$ & 下垂体機能低下症、慢性胃炎 & 心窩部痛、胸焼け、嘔吐、のぼせ \\
\hline 20 & $40 \mathrm{~F}$ & うつ病、慢性胃炎 & 腹満、のぼせ、不安 \\
\hline 21 & $50 \mathrm{M}$ & 大腸癌、骨転移、肝転移 & 前胸部痛、左肩痛、腰痛 \\
\hline 22 & $60 \mathrm{M}$ & 不安障害、狭心症、高血圧 & 動悸、胸㾇、不安 \\
\hline 23 & $66 \mathrm{M}$ & 食道癌 & 胸㾝、全身倦忠感、食思不振 \\
\hline 24 & $70 \mathrm{M}$ & 胃癌術後、腰部脊柱管狭窄症 & のぼせ、胸焼け、下肢疩れ \\
\hline 25 & $76 \mathrm{M}$ & 不安障害、狭心症、腰部脊柱管狭窄症 & 不安、凍瘡、嗄声 \\
\hline 26 & $40 \mathrm{~F}$ & 慢性胃炎、緊張型頭痛 & 心窩部痛、頭痛、腰痛 \\
\hline 27 & $58 \mathrm{~F}$ & メニエル症候群、慢性胃炎 & 心窩部痛、食思不振、眩暈 \\
\hline 28 & $78 \mathrm{~F}$ & 下肢静脈瘤、レイノ一病、慢性胃炎 & 心窩部不快感、浮腫、冷え症 \\
\hline 29 & $78 \mathrm{~F}$ & 慢性胃炎、不眠症 & 心窩部痛、食思不振、耳鳴 \\
\hline 30 & $54 \mathrm{M}$ & 脳梗塞後遺症、頸部脊柱管狭窄症 & 心窩部痛、左上下肢㾝れ \\
\hline
\end{tabular}

有効例 : 症例 $1 \sim 25$ 、無効例 : 症例 $26 \sim 30$

虚に水毒を兼ねた病態に本方が著効した 3 症例を経 験した。この 3 例と同様の病態を呈した症例に本方 を処方し, 有効例の回顧的解析から新たな知見を得 たので報告する。

\section{症例}

〔症例 1 〕 36歳, 女性。

主 訴: 不妊, 腹満, 全身倦总感, 易疲労感。

既往歴：特記すべきことなし。

家族歴：脳梗塞 (祖母)。

現病歴：1999年に結婚，2002年 2 月に不妊治療を 開始した。2004年よりそ精子無力症のため卵細胞質 内精子注入法 (ICSI) を 7 回施行したが着床しな かった。産婦人科で施行したホルモン值, 受精卵, 子宮内膜厚, 不育症検査等には異常なかった。この ため漢方治療を希望し，2006年 9 月当科を受診。 $<$ 初診時の和漢診療学的所見 $>$

自覚症状：全身倦总感, 易疲労感, 日中の眠気,
朝起きにくい，放屁が多い，腹満，抑森筙傾向，立ち くらみ，車酔いしやすい，のぼせ，頭重感，浮腫傾 向，大小便に異常無し。

他覚所見：身長 $165 \mathrm{~cm}$, 体重 $56 \mathrm{~kg}$, 血圧108/64 $\mathrm{mmHg}$, 脈拍 $69 /$ 分, 整, 体温 $36.0^{\circ} \mathrm{C}$ 。脈候はやや 浮, やや小, 弦, 渋, 緊張はやや弱。舌候では舌質 は正常紅, 腫大, 歯痕を認め, 乾湿中等度の微白苔 を被っていた。腹候は腹力中等度で心下㾂鞕, 胃部 振水音, 両側腹直筋緊張, 心下悸, 臍上悸, 臍下悸, 左臍傍圧痛, 回盲部圧痛, 上腹部に著明な鼓音を認 めた。

$<$ 治療経過 $>$

気鬱，気虚に水毒を兼ねた病態と考えツムラ获苓 飲合半夏厚朴湯エキス（7.5g/日）を投与した。4 週後には全身倦总感，腹満等の自覚症状が消失した。 2007年 2 月に 8 回目の ICSI を施行し妊娠した。妊 娠第 6 週の同年 4 月よりッムラ半夏厚朴湯エキス 
表 2 症例の脈候および舌候

\begin{tabular}{|c|c|c|c|c|c|c|c|c|c|c|}
\hline 症例 & 浮沈 & 緊張 & 大小 & 滑渋 & 舌質の色調 & 腫大 & 歯痕 & 舌尖紅 & $\begin{array}{c}\text { 舌 } \\
\text { 乾湿 }\end{array}$ & $\begin{array}{l}\text { 苔 } \\
\text { 色調 }\end{array}$ \\
\hline 1 & やや浮 & やや弱 & やや小 & 渋 & 正常紅 & + & + & - & 中 & 微白 \\
\hline 2 & 中 & 中 & 中 & 中 & 正常紅 & + & + & - & 湿潤 & 微白 \\
\hline 3 & 中 & 中 & 中 & 橴 & 正常紅 & + & + & + & 湿潤 & 微白 \\
\hline 4 & 中 & 中 & 中 & 中 & 暗赤紅 & + & - & + & 湿潤 & 白 \\
\hline 5 & 中 & 中 & 中 & 渋 & 正常紅 & + & + & + & 中 & 白 \\
\hline 6 & 中 & 中 & 中 & 中 & 正常紅 & + & - & - & 中 & 微白 \\
\hline 7 & 浮 & 中 & 中 & 渋 & 正常紅 & + & + & - & 湿潤 & 微白 \\
\hline 8 & 中 & 中 & 中 & 中 & 正常紅 & + & + & + & 中 & 微白 \\
\hline 9 & 中 & やや弱 & やや小 & 渋 & 淡白紅 & + & - & - & 湿潤 & 微白 \\
\hline 10 & 中 & やや弱 & やや小 & 渋 & 正常紅 & + & + & + & 中 & 白 \\
\hline 11 & 中 & 中 & 中 & 中 & 正常紅 & + & + & + & 中 & 微白 \\
\hline 12 & 中 & 中 & 中 & 中 & 喑赤紅 & + & + & - & 中 & 白黄 \\
\hline 13 & 中 & 中 & 中 & 中 & 正常紅 & + & + & - & 中 & 微白 \\
\hline 14 & やや沈 & やや弱 & やや小 & 渋 & 暗赤紅 & + & + & - & 中 & 白黄 \\
\hline 15 & 中 & 中 & 中 & 渋 & 正常紅 & + & + & - & 湿潤 & 白 \\
\hline 16 & 浮 & 中 & 中 & 渋 & 正常紅 & + & - & - & 乾燥 & 白 \\
\hline 17 & 中 & 中 & 中 & 中 & 正常紅 & - & - & - & 中 & 微白 \\
\hline 18 & 中 & 中 & 中 & 渋 & 正常紅 & + & + & - & 乾燥 & 白黄 \\
\hline 19 & 中 & 中 & 中 & 渋 & 正常紅 & + & - & + & 湿潤 & 白黄 \\
\hline 20 & やや浮 & 中 & 中 & 中 & 正常紅 & + & + & - & 湿潤 & 白 \\
\hline 21 & 浮 & 中 & 中 & 渋 & 喑赤紅 & + & - & - & 中 & 白 \\
\hline 22 & 中 & 中 & 中 & 中 & 喑赤紅 & + & - & - & 乾燥 & 白黄 \\
\hline 23 & やや浮 & 中 & 中 & 渋 & 正常紅 & + & - & - & 中 & 白 \\
\hline 24 & 中 & やや弱 & やや小 & 渋 & 喑赤紅 & + & - & - & 乾燥 & 白 \\
\hline 25 & 中 & 中 & 中 & 渋 & 正常紅 & - & - & + & 乾燥 & 白黄 \\
\hline 26 & 中 & 中 & 中 & 渋 & 正常紅 & + & + & + & 中 & 白 \\
\hline 27 & やや浮 & 中 & 中 & 啮 & 淡白紅 & + & + & - & 湿潤 & 微白 \\
\hline 28 & 中 & 中 & 中 & 渋 & 暗赤紅 & + & + & - & 中 & 白黄 \\
\hline 29 & 中 & 中 & 中 & 中 & 正常紅 & + & - & - & 中 & 白黄 \\
\hline 30 & 中 & 中 & 中 & 渋 & 暗赤紅 & + & - & - & 乾燥 & 微黄 \\
\hline
\end{tabular}

脈候の数遅、緊緩は、全例がそれぞれ中間、弦であった。 中間および中等度はいずれも中で表記した。

（5.0g/日）に転方し，以後順調に経過した。妊娠 第30週頃より便秘が出現したため, 妊娠第33週の同 年11月よりッムラ当帰药薬散エキス $(5.0 \mathrm{~g} /$ 日) に 転方した。当帰药薬散服用後は便秘も解消し, 妊娠 第38週の同年12月に正常分婏にて $2700 \mathrm{~g}$ の女児を出 産した。

[症例 2〕49歳, 女性。

主 訴：ホットフラッシュ $(\mathrm{HF})$, 心窩部不快感。

既往歴：特記すべきことなし。

家族歴：骨髄異形成症候群 (父)。

現病歴：2003年 9 月に左乳癌（ $\Pi_{\mathrm{B}}$ 期）にて乳房 切除術を施行された。その後, クエン酸夕モキシフ エンを投与され無月経となり，HF，発汗等の更年 期症候群の症状が出現した。2006年 2 月に抗癌剤が エキセメスタンに変更され，HF，発汗が増悪し， 動悸, 心窩部不快感などの症状も伴った。このため
漢方治療を希望し，同年 6 月当科を受診した。 $<$ 初診時の和漢診療学的所見 $>$

自覚症状: HF, 発汗, 動悸, 心窩部不快感, 胸 焼け, 全身倦总感, 易驚性, 抑鬱傾向, 咽中采彎, 腹満, 頭重感, 眩軍感, 浮腫傾向, 軟便傾向 ( 1 回/ 2 日)，夜間尿なし。

他覚所見：身長 $155 \mathrm{~cm}$, 体重 $47 \mathrm{~kg}$, 血圧 $98 / 64 \mathrm{mmHg}$, 脈拍 $76 /$ 分, 整, 体温 $36.4{ }^{\circ} \mathrm{C}$ 。脈候は浮沈中間, や や弦, 緊張は中等度。舌候では舌質は正常紅で, 腫 大，歯痕を認め，やや湿潤した微白苔を被っていた。 腹候は腹力ゃや軟弱で, 両側腹直筋緊張, 胃部振水 音, 心下悸, 臍上悸, 回盲部圧痛, 小腹不仁, 腹部 全体に著明な鼓音を認めた。

$<$ 治療経過 $>$

症例 1 と同様に気䅧, 気虚に水毒を兼ねた病態と 考えツムラ获苓飲合半夏厚朴湯エキス $(7.5 \mathrm{~g} /$ 日 ) 
表 3 症例の腹候

\begin{tabular}{|c|c|c|c|c|c|c|c|}
\hline 症例 & 腹力 & 心下㾙鞕 & 胸脇苦満 & 胃部振水音 & 腹動 & 下腹部圧痛 & 小腹不仁 \\
\hline 1 & 中等度 & + & - & + & +++ & ++ & - \\
\hline 2 & やや軟弱 & - & - & + & ++ & + & + \\
\hline 3 & やや軟弱 & - & - & - & +++ & ++ & - \\
\hline 4 & 中等度 & + & - & - & + & ++ & - \\
\hline 5 & やや軟弱 & + & - & - & +++ & ++ & + \\
\hline 6 & やや軟弱 & - & - & + & + & - & + \\
\hline 7 & 中等度 & + & - & - & + & - & + \\
\hline 8 & 中等度 & + & - & - & + & ++ & + \\
\hline 9 & やや軟弱 & + & - & + & ++ & - & - \\
\hline 10 & やや充実 & + & - & - & + & ++ & - \\
\hline 11 & 中等度 & - & - & + & - & - & - \\
\hline 12 & 中等度 & + & - & + & ++ & +++ & - \\
\hline 13 & 中等度 & + & - & - & ++ & - & + \\
\hline 14 & 中等度 & - & - & - & ++ & ++ & + \\
\hline 15 & やや軟弱 & - & - & - & ++ & - & + \\
\hline 16 & 中等度 & + & - & - & + & - & - \\
\hline 17 & 中等度 & + & - & - & ++ & - & + \\
\hline 18 & やや軟弱 & + & + & - & + & ++ & + \\
\hline 19 & 中等度 & + & - & - & +++ & ++ & - \\
\hline 20 & 中等度 & + & - & + & + & ++ & - \\
\hline 21 & 中等度 & + & - & + & - & - & - \\
\hline 22 & 中等度 & + & - & - & + & ++ & + \\
\hline 23 & 中等度 & + & - & + & - & - & + \\
\hline 24 & やや軟弱 & - & - & + & - & - & + \\
\hline 25 & やや軟弱 & - & - & + & + & - & + \\
\hline 26 & 中等度 & + & - & - & - & +++ & - \\
\hline 27 & やや充実 & + & - & - & - & + & + \\
\hline 28 & やや軟弱 & + & - & - & - & - & + \\
\hline 29 & やや軟弱 & + & - & - & - & - & + \\
\hline 30 & 中等度 & - & - & - & - & + & + \\
\hline
\end{tabular}

腹直竻緊張と腹部鼓音は全例で認められた。

腹動（心下悸・臍上悸・臍下悸）と下腹部圧痛点は所見の認められた数により+〜+++で表記した。

を投与した。服用 4 週後には HF，発汗は同様だが， それ以外の自覚症状は消失した。服用 8 週後には軽 度の HF のみとなった。以後も続服中であるが服用 90 週の 2008 年 3 月まで良好な経過をとっている。

〔症例 3 〕4歳, 女性。

主 訴：腹満, 下痢, 頭重。

既往歴：特記すべきことなし。

家族歴：特記すべきことなし。

現病歴：2002年頃から腹満，水椂性下痢（2３

回/日)，頭重があったが放置していた。症状が持続 し改善しなかったため2004年に近医にて上部および 下部消化管内視鏡検査，腹部超音波検査を施行され たが異常は認められず過敏性腸症候群と診断された。 その後, 種々の西洋医学的な加療を受けたが軽快し なかった。このため漢方治療を希望し2007年 2 月当 科を受診した。

$<$ 初診時の和漢診療学的所見 $>$
自覚症状：腹満 (午後からが特に著しい), 頭重, 全身倦总感，易疲労感，易驚性，頭重感，咽中多變， 胸満感，眩暈感，のぼせやすい，身体が重い，朝の こわばり, 水様性下痢 ( $2 \sim 3$ 回/日), 夜間尿 1 回。 他覚所見：身長 $162 \mathrm{~cm}$, 体重 $60 \mathrm{~kg}$, 血圧 $110 / 68$ $\mathrm{mmHg}$, 脈拍 $72 /$ 分, 整, 体温 $36.3^{\circ} \mathrm{C}$ 。脈候は浮沈 中間, 弦, 渋, 緊張は中等度。舌候では舌質は正常 紅で，腫大，歯痕を認め，湿潤した白苔を被ってい た。腹候は腹力やや軟弱で, 両僋腹直筋緊張, 心下 悸, 臍上悸, 臍下悸, 両側臍傍圧痛, 上腹部に著明 な鼓音を認めた。

$<$ 治療経過 $>$

症例 1 および 2 と同様の病態と考え获苓飲合半夏 厚朴湯エキス（7.5g/日）を投与した。投与 4 週後 には腹満, 下痢㧍よび諸症状が消失し, 頭重と眩暈 感を残すのみとなった。投与 8 週後には頭重および 眩軍感も消失した。以後も続服中であるが投与 55 週 
の2008年 3 月まで良好な経過をとっている。

\section{多数例での検討}

获苓飲合半夏厚朴湯が奏効した上記 3 症例におい

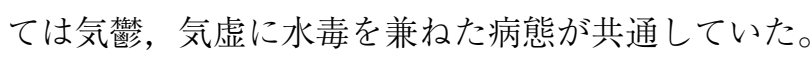

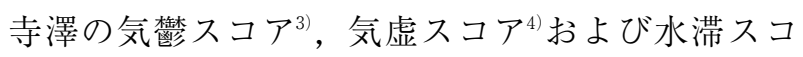
$ア^{5)}$ の基準を満たした 30 症例（上述の 3 症例を含 む）に対して获苓飲合半夏厚朴湯を投与した。同方 を投与後 8 週間以内に主訴が, Visual Analogue Scale にて投与前の $50 \%$ 以下になったものを有効，それ以 外を無効として検討を行なった。また自覚症状掞よ び他覚所見について有効と無効の 2 群間での比較に は $\chi^{2}$ 検定を用い，有意水準を $\mathrm{p}<0.05$ とした。その 結果, 全30症例中, 有効は25例, 無効は 5 例であっ た。平均年齢は有効例49.5歳, 無効例61.6歳と無効 例が若干高齢であったが, 男女比に差はみられな かった。対象の全30症例の背景, 自覚症状を表 1 ,

脈候，舌候を表 2 ，腹候を表 3 に提示した。

自覚症状では，のぼせが有効例で有意に多く認め られた $(\mathrm{p}<0.05)$ 。また心窩部痛あるいは心窩部不 快感などの心窩部の症状を訴えた症例では胸焼け， 動悸, 胸部圧迫感 (胸痺), 呼吸困難などの胸部症 状を伴うものでは有効で, 伴わないものでは無効で あった $(\mathrm{p}<0.01)$ 。心窩部の症状を伴わず胸部症状 を訴えた 8 例にも获苓飲合半夏厚朴湯は有効であっ た（症例 4, 6, 7, 9, 11, 13, 19, 23)。

他覚的所見では表 2 に提示した脈候および舌候に おいては有効例と無効例に特徴的な違いは認められ なかった。

表 3 に提示した腹候においては有効例では胃部振 水音, 腹動の少なくとも一方を認めたのに対し, 無 効例では両徴候をともに認めなかった。特に腹動 は有効例で無効例に比較して有意に多くみられた $(\mathrm{p}<0.001)$ 。

\section{考察}

获苓飲合半夏厚朴湯は获苓飲と半夏厚朴湯の 2 方 剂の合方であるが，第二次世界大戦前の大塚敬節の 創意になる合方である可能性が強いと考えられてい る処方である ${ }^{1)}$

本方の使用目標については「体力中等度あるいは やや低下した人の抑缶状態, 咽喉部異物感を目標に 用いる。腹部は腹力中等度ないしやや弱く, 軽度の 心下㾂鞕と振水音を認めることが多い。眩量, 動悸, 不安, 悪心, 胸焼け, 軽度の呼吸困難などを伴う。」
と記載された成書をみとめるのみであっだ'7)。この 他には緒言で提示した大塚敬節の報告 ${ }^{1)}$ のであっ た。目標とする自覚症状として「動悸, 胸焼け, 呼 吸困難といった胸部症状を伴う」と記載されており， 本稿の検討結果でも胸部症状が有効例に高率に認め られた点が一致しており興味深い。上記の 3 文献に 共通する目標は胃部振水音（胃内停水）であり, 今 回の検討でも获苓飲合半夏厚朴湯の有効例に特徵的 な所見であった点が特筆される。

获苓飲合半夏厚朴湯の適応症は不安神経症, 神経 性胃炎, 悪阻, 溜飲, 胃炎とされ ${ }^{8}$, これらの疾患 に用いられることが多い。しかし術後吻合部狭窄9), 過敏性腸症候群 ${ }^{10)}$, 咽喉頭異常感症 ${ }^{11)}$, 難治性眩暈 ${ }^{12}$ に対して本方が有効であったとする報告も散見され

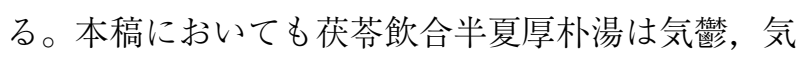
虚に水毒を兼ねた病態に投与したところ表 1 に提示 した種々の疾患に対して有効であった。

获苓飲合半夏厚朴湯の使用を考慮する際には気麓, 気虚に水毒を兼ねた病態であることを確認し, 従来 重視すべきであるとされた所見に加え，自覚的には のぼせが存在すること, 心窩部痛, 心窩部不快感を 訴えるものでは胸部症状を伴うこと, 他覚的には腹 診において腹動あるいは胃部振水音が存在すること を検討することにより高い精度で処方決定すること が可能になると推測された。さらには，これまで適 応に挙げられることの無かった病態に対しても本方 を応用しうる可能性が示唆された。

附記 : 本稿で提示した症例 $1 \sim 3$ は第59回日本東洋 医学会総会（仙台・2008年）において報告した。

本稿の症例 $1 \sim 14 ， 16 \sim 21 ， 23 \sim 28 ， 30$ にはツムラ 获苓飲合半夏厚朴湯エキス顆粒 $7.5 \mathrm{~g} /$ 日あるいは $5.0 \mathrm{~g} /$ 日を投与した。

本稿の症例 $15,22,29$ に投与した获苓飲合半夏厚朴 湯の構成と生薬集散地は以下の通りである。获苓飲合 半夏厚朴湯: 获荅 $(6.0 \mathrm{~g}$, 中国), 白术 $(4.0 \mathrm{~g}$, 中国), 人参 $(4.0 \mathrm{~g}$, 韓国)，陳皮 $(3.5 \mathrm{~g}$, 日本)，枳実 $(3.0 \mathrm{~g}$, 中国), 生姜 $(1.0 \mathrm{~g}$, 中国), 半夏 $(8.0 \mathrm{~g}$, 中国), 厚 朴 $(3.0 \mathrm{~g}$, 日本), 蘇葉 $(2.0 \mathrm{~g}$, 中国)。

\section{文献}

1 ）小山誠次: 获苓飲合半夏厚朴湯, 古典に基づくエ キス漢方方剤学，549-552，メディカルユーコン， 
京都 (1998)

2 ) 大塚敬節：半夏厚朴湯について, 漢方と漢薬， $5,1-13$ (1938)

3 ) 寺澤捷年：症例から学ぶ和漢診療学 第 2 版, 23 , 医学書院, 東京 (1998)

4) 寺澤捷年：症例から学ぶ和漢診療学 第 2 版, 17 , 医学書院, 東京 (1998)

5 ) 寺澤捷年：症例から学ぶ和漢診療学 第 2 版, 57 , 医学書院，東京 (1998)

6 ）長谷川弥人, 大塚恭男, 山田光㴰, 他 : 漢方製剂 活用の手引き一証の把握と処方鑑別のために一, 254-255，臨床情報センター，東京（1998）

7 ) 寺澤捷年：症例から学ぶ和漢診療学 第 2 版, 296, 医学書院，東京 (1998)
8 ) 日本医薬品集フォーラム：日本医薬品集 医療薬 2007年版，2720，じほう，東京（2007）

9 ) 酒向猛, 滝本一, 武内有城, 他: 術後吻合部狭乍 に対するツムラ获苓飲合半夏厚朴湯の使用経験,

Prog. Med., 16, 1517-1519 (1996)

10）山本晴義, 江花昭一, 津久井要, 他: 各科領域に 扔ける心身症と漢方の有用性 過敏性腸症候群に 対する获荅飲合半夏厚朴湯の使用経験, 心身医療, 4, 526-529 (1992)

11）川崎順久, 甲能直幸, 川井田政弘: 咽喉頭異常感 症に対するッムラ获苓飲合半夏厚朴湯の使用経験, Prog. Med., 11，3107-3110（1991）

12）山崎可夫：難治性めまいに対する获苓飲合半夏厚 朴湯の著効例, 現代東洋医学, 11, 375-376 (1990) 